\title{
Kemampuan Numerik Siswa Pesisir SMP Negeri Di Kabupaten Wakatobi
}

\author{
(Numericalabilityof Costal Students Of State Junior High School In Wakatobi)
}

\author{
Halyadin', Anwar Bey², Kadir², Hafiludin Samparadja ${ }^{2}$ \\ ${ }^{1}$ Alumnus Jurusan Pendidikan Matematika FKIP Universitas Halu Oleo; Co-author: \\ yadinhal536@gmail.com \\ ${ }^{2}$ Dosen Pendidikan Matematika FKIP dan PPS Universitas Halu Oleo \\ ${ }^{3}$ Dosen Pendidikan Matematika FKIP Universitas Halu Oleo
}

\begin{abstract}
Abstrak: Penelitian ini bertujuan untuk mendeskripsikan: (1) kemampuan numerik siswa pesisir SMP Negeri di Kabupaten Wakatobi \& (2) perbandingan kemampuan numerik siswa pesisir SMP Negeri pada tiap pulau yang ada di Kabupaten Wakatobi. Populasi penelitian ini adalah siswa kelas VIII SMP Negeri di Kabupaten Wakatobi. Teknik pengambilan sampel dalam penelitian ini menggunakan sampel total. Teknik pengumpulan data dilakukan dengan pemberian tes kemampuan numerik (TKN) berbentuk pilihan ganda. Hasil penelitian ini menunjukkan bahwa kemampuan numerik siswa pesisir SMP Negeri di Kabupaten Wakatobi sangat rendah dengan rata-rata 29,85. Rata-rata Kemampuan numerik siswa pesisir SMP Negeri di Kabupaten Wakatobi berurutan adalah pulau Wangi-wangi 29,34, pulau Kaledupa 24,94, pulau Tomia 35,24, \& pulau Binongko 29,27.
\end{abstract}

Kata kunci: Kemampuan Numerik, Siswa Pesisir.

\begin{abstract}
This study aims to describe: (1) the numerical ability of coastal students in the State Middle School in Wakatobi Regency \& (2) a comparison of the numerical abilities of coastal SMP students in each island in Wakatobi Regency. The population of this study was the eighth grade students of the National Middle School in Wakatobi Regency. The sampling technique in this study used a total sample. The technique of data collection is done by giving a multiple choice numerical ability test (TKN). The results of this study indicate that the numerical ability of coastal junior high school students in Wakatobi District is very low with an average of 29.85. The average numerical ability of the National Middle School coastal students in Wakatobi Regency is Wangiwangi Island 29.34, Kaledupa Island 24.94, Tomia Island 35.24, \& Binongko Island 29.27.
\end{abstract}

Keywords: Numerical Ability, Coastal Students.

\section{PENDAHULUAN}

Indonesia memiliki beraneka ragam bahasa dan sumber daya alam khususnya sumber daya pesisir yang sangat melimpah. Wilayah pesisir adalah wilayah pertemuan antara daratan dan lautan yang merupakan tempat hidup berbagai ekosistem yang saling berinterakasi sehingga memungkinkan dapat diakses dengan mudah oleh aktivitas manusia.

Sumber daya pesisir tersebut belum dimanfaatkan secara optimal untuk kesejahteraan hidup masyarakat pesisir. Perilaku desruktif seperti pemanfaatan perluasan daratan untuk reklamasi pantai, penebangan pohon bakau (mangrove), pemboman ikan, pencemaran limbah dan lain-lain telah memperlaju kerusakan sumber daya pesisir tersebut.

Wilayah pesisir adalah wilayah pertemuan antara daratan dan lautan dan sebagai tempat hidup beragam ekosistem yang saling berinteraksi sehingga memungkinkan dapat diakses dengan mudah oleh aktivitas manusia. Masyarakat yang tinggal pada wilayah pesisir dan pulau-pulau kecil disebut masyarakat pesisir seperti nelayan, pembudidaya, pemasar ikan, pengolah hasil laut, dan masyarakat pesisir lainnya yang menggantungkan kehidupannya dari 
sumber daya kelautan dan perikanan (Kadir, 2009: 31). Pendapat ini sejalan dengan pernyataan Kay dan Alder (1998) berpendapat " the band of dry land adjancent ocean space (water and submegend land) in wich terrestrial processes and land uses directly affect oceanic processes and uses, and vice versa". Diartikan bahwa wilayah pesisir adalah wilayah yang merupakan tanda atau batasan wilayah daratan dan wilayah perairan yang mana proses kegiatan atau aktivitas bumi dan penggunaan lahan masih mempengaruhi proses dan fungsi kelautan.

Ekosistem wilayah pesisir dan lautan dipandang dari dimensi ekologis memiliki 4 fungsi/peran pokok bagi kehidupan manusia, yaitu: (1) sebagai penyedia sumber daya alam sebagaimana dinyatakan di atas, (2) penerima limbah, (3) penyedia jasa-jasa pendukung kehidupan manusia (life support services), (4) penyedia jasa-jasa kenyamanan (amenity services) (Bangen, 2001: 62). Dari pernyataan ini menujukan bahwa sumber daya pesisir memiliki manfaat yang begitu banyak, jika dikelola dengan baik dan bijaksana.

Definisi lain juga dikemukakan oleh Suprihayono (2007: 16), wilayah pesisir adalah wilayah pertemuan antara daratan dan laut ke arah darat wilayah pesisir meliputi bagian daratan, baik kering maupun terendam air, yang masih dipengaruhi oleh sifat-sifat laut seperti pasang surut, angin laut, dan perembesan air asin. Sedangkan ke arah laut wilayah pesisir mencakup bagian laut yang masih dipengaruhi oleh proses alami yang terjadi di darat seperti sedimentasi dan aliran air tawar, maupun yang disebabkan karena kegiatan manusia di darat seperti penggundulan hutan dan pencemaran. Pengertian wilayah pesisir menurut kesepakatan terakhir internasional adalah merupakan wilayah peralihan antara laut dan daratan, ke arah darat mencakup daerah yang masih terkena pengaruh percikan air laut atau pasang surut, dan ke arah laut meliputi daerah paparan benua (continental shelf) (Dahuri, dkk. 2001). Jadi, wilayah pesisir dapat diartikan sebagai wilayah yang dipengaruhi oleh proses alami yang terjadi di darat dan proses alami yang terjadi di laut.

Wakatobi merupakan wilayah pesisir yang resmi ditetapkan sebagai salah satu kabupaten pemekaran di Sulawesi Tenggara yang terbentuk pada tanggal 18 Desember 2003, berdasarkan UndangUndang nomor 23 tahun 2003 tentang pembentukan Kabupaten Bombana, Kabupaten Wakatobi dan Kabupaten Kolaka Utara. Kabupaten Wakatobi terdiri dari empat pulau utama, yaitu Wangiwangi, Kaledupa, Tomia, dan Binongko. Wakatobi adalah singkatan nama dari keempat pulau utama tersebut.

Kabupaten Wakatobi menjadi salah satu daerah dari 12 daerah di Indonesia yang terpilih sebagai lokasi uji coba kurikulum kemaritiman. Secara geostrategis, Kabupaten Wakatobi terletak pada posisi yang sangat strategis dikarenakan perairan laut Kabupaten Wakatobi dilalui jalur pelayaran kawasan Timur dan Barat Indonesia. Ditinjau dari lokasi bioregion, letak geografis Kabupaten Waktobi sangat penting yakni berada pada kawasan yang sangat potensial yang diapit oleh Laut Banda dan Laut Flores yang memiliki potensi sumber daya keragaman hayati kelautan dan perikanan yang cukup besar. Selain itu, Kabupaten Wakatobi berada pada Pusat Kawasan Segitiga Karang Dunia (Coral Tri-Angle Center) yang meliputi enam Negara yakni Indonesia, Malaysia, Filipina, Papua New Guine, solomon island dan Timor Leste. Untuk menunjang uji coba kurikulum tersebut para Kepala Sekolah, Guru, Pengawas, dan Dinas Pendidikan akan memberikan masukan kepada Kementerian Pendidikan dan Kebudayan Republik Indonesia, sehubung langkah pelaksanaannya di sekolah. Untuk 
tahap awal, tenaga pendidik di tingkat TK sampai SMA/SMK diberikan pelatihan oleh kementerian.

Konsep dari Kurikulum Kemaritiman akan diterapkan sesuai kurikulum yang ada di sekolah. Mata pelajaran yang disajikan sesuai dengan kondisi alam yang ada di Wakatobi sehingga siswa lebih mengenal potensi yang ada di daerahnya. Namun, banyak potensi wilayah pesisir yang belum mendapatkan perhatian dari setiap lembaga pendidikan. Masyarakat daerah pesisir umumnya memiliki kualitas pendidikan yang relatif rendah dibandingkan dengan masyarakat di daerah pusat kota. Selaras dengan yang dikatakan Kusnadi (2007) bahwa kondisi masyarakat nelayan atau masyarakat pesisir di berbagai kawasan secara umum dapat dicirikan dengan kemiskinan, keterbelakangan sosial budaya, dan rendahnya kualitas SDM. Persepsi tentang kemiskinan seringkali tertuju pada nelayan buruh, karena pendapatan mereka cenderung pas-pasan dan bersifatfluktuatif. Pendapatan mereka tergantung pada cuaca dan keahlian dalam memancing. Realitas ini juga yang menjadi salah satu sebab mengapa tingkat pendidikan anak-anak nelayan cenderung rendah. Tak sedikit anak yang hanya sampai di tingkat sekolah dasar saja. Setelah lulus SD atau SMP mereka biasanya ikut pergi melaut, seperti bapak atau saudara laki-lakinya.

Masyarakat pesisir yang di dominasi oleh usaha perikanan pada umumnya masih berada pada garis kemiskinan, mereka tidak mempunyai pilihan mata pencaharian, memiliki tingkat pendidikan yang rendah, tidak mengetahui dan menyadari kelestarian sumber daya alam dan lingkungan (Lewaherilla, 2002).

Kultur daerah pesisir yang hampir seluruh masyarakatnya bekerja sebagai nelayan akan berakibat pendidikan yang berbasis pada laut. Potensi pesisir sangat potensial dikembangkan melalui pembelajaran matematika, dengan menciptakan generasi muda yang semangat dan berpola pikir matematis. Walaupun demikian, pemerintah belum mencurahkan perhatian lebih untuk mengembangkan potensi pesisir dalam pembelajaran (Rustam, 2015:97). Sebagaimana dijelaskan Kadir (2009: 2) bahwa banyak daerah menjadikan mata pelajaran bahasa daerah sebagai mata pelajaran muatan lokal untuk melestarikan bahasa daerah yang digunakan masyarakat setempat. Inisiatif ini bukan sesuatu yang salah, tetapi sayangnya banyak potensi daerah pesisir yang juga mesti mendapat perhatian karena lebih dibutuhkan tetapi belum mendapatkan perhatian dari setiap lembaga pendidikan

Pemanfaatan sumberdaya pesisir bagi kehidupan masyarakat pesisir adalah kegiatan utama untuk memenuhi kebutuhan ekonomi mereka. Kegiatan ini dapat dimulai pada siswa SMP pesisir sebagai tulang punggung pembangunan wilayah pesisir kedepan.. Anak-anak dituntut untuk ikut mencari nafkah, menanggung beban kehidupan rumah tangga, dan mengurangi beban tanggung jawab orangtuannya. Oleh karena itu, dibutuhkan kesadaran bersama untuk lebih memperhatikan potensi pesisir yang ada. Hal tersebut merupakan salah satu faktor yang menyebabkan pemahaman siswa pesisir menjadi rendah khususnya pada mata pelajaran matematika.

Pembelajaran matematika akan mudah dipelajari oleh orang-orang yang mempunyai kemampuan numerik yang tinggi. Hal ini dikarenakan sebagian besar materi yang ada dalam mata pembelajaran matematika membutuhkan banyak perhitungan, membutuhkan kemampuan untuk menyelesaikan permasalahan matematika tersebut. Kemampuan numerik itu sendiri merupakan kemampuan khusus dalam hitung 
menghitung sehingga kemampuan numerik mempengaruhi kemampuan siswa dalam memahami dan menyelesaikan soal matematika.

Robbins (2006: 46) mengemukakan bahwa kemampuan merupakan suatu kapasitas individu untuk mengerjakan berbagai tugas dalam suatu pekerjaan. Sedangkan numerik adalah semua hal yang berwujud nomor atau angka yang bersifat sistem angka, data statistik atau data yang membutuhkan pengelolaan yang cermat. Menurut Leoni (2008: 1), kemampuan numerik yaitu kemampuan yang berhubungan dengan angka dan kemampuan untuk berhitung. Dengan kemampuan numerik yang dimiliki siswa akan membantu mereka dalam memahami materi matematika dan akan membantu mereka menganalisis setiap permasalahan matematika serta membantu mereka menerapkan konsep matematika dalam kehidupan sehari-hari. Dengan kemampuan numerik yang baik siswa tidak akan kesulitan belajar matematika.

Pada dasarnya kemampuan numerik tiap anak itu berbeda-beda, ada anak yang begitu tinggi kecerdasan numeriknya namun ada juga yang sebaliknya dan hal tersebut berpengaruh dalam jalannya pembelajaran. Pada kenyataanya sebagian siswa mengeluh kesulitan mempelajari matematika karena matematika tidak hanya sekedar menguasai konsep tetapi juga harus menghitung dengan rumus-rumus. Tidak sedikit siswa yang menguasai konsep tetapi ketika mereka sudah mendapati permasalahan dalam bentuk hitungan mereka kesulitan mengerjakannya.

Kemampuan numerik adalah kermampuan memahami hubungan angka dan memecahkan masalah yang berhubungan dengan konsep-konsep bilangan (Fudiyartanta, 2004: 68). Berbeda dengan Gardner (1993) menyebut kemampuan numerik dan bakat numerik, yaitu: kecerdasan dalam menggunakan angka-angka dan penalaran. Jadi, kemampuan numerik yaitu kemampuan berhitung, menalar angka-angka, menggunakan atau memanipulasi relasi angka, membandingkan antara angka dan menguraikan secara logis. Sehubungan dengan penalaran, maka kemampuan memahami juga dapat dilihat dari kemampuan siswa dalam memecahkan masalah atau menerapkan konsep-konsep numerik untuk memecahkan masalah. Seseorang mempunyai kecerdasan numerik, pada umumnya mempunyai cara berpikir yang teratur dalam mengerjakan sesuatu dan menyelesaikan masalah. Kemampuan numerik dalam penelitian ini ada juga yang mengatakan dengan istilah number sense.

Mc. Intosh, Reys and Reys (1999: 61) mengembangkan sebuah kerangka (indikator) yang dapat digunakan untuk menilai kemampuan number sense. Kerangka ini tidak melihat faktor yang dapat mempengaruhi kemampuan number sense, tetapi dapat dijadikan tolak ukur untuk melihat atau menilai kemampuan number sense yang dimiliki siswa. Indikator tersebut dirumuskan pada Tabel 1.

Tabel 1. Indikator Kemampuan Numerik

\begin{tabular}{|c|c|c|c|}
\hline \multirow{7}{*}{$\begin{array}{l}\text { 1. Pengetahuan } \\
\text { Fasilitas } \\
\text { Bilangan }\end{array}$} & & \multirow{3}{*}{ 1.1 Urutan Bilangan } & \multirow{2}{*}{$\begin{array}{l}\text { 1.1.1 Nilai Tempat } \\
\text { 1.1.2 Hubungan antar Tipe Bilangan }\end{array}$} \\
\hline & & & \\
\hline & & & Mengurutkan \\
\hline & dan & & Menurut Jenisnya \\
\hline & tentang & & 1.2.1 Grafis/Simbol \\
\hline & & 1.2 Representasi Bentuk & 1.2.2 Kesetaraan Bentuk Bilangan \\
\hline & & Bilangan & $\begin{array}{l}\text { 1.2.3 Perbandingan dengan } \\
\text { Ukur }\end{array}$ \\
\hline
\end{tabular}


Lanjutan Tabel 1. Indikator Kemampuan Numerik

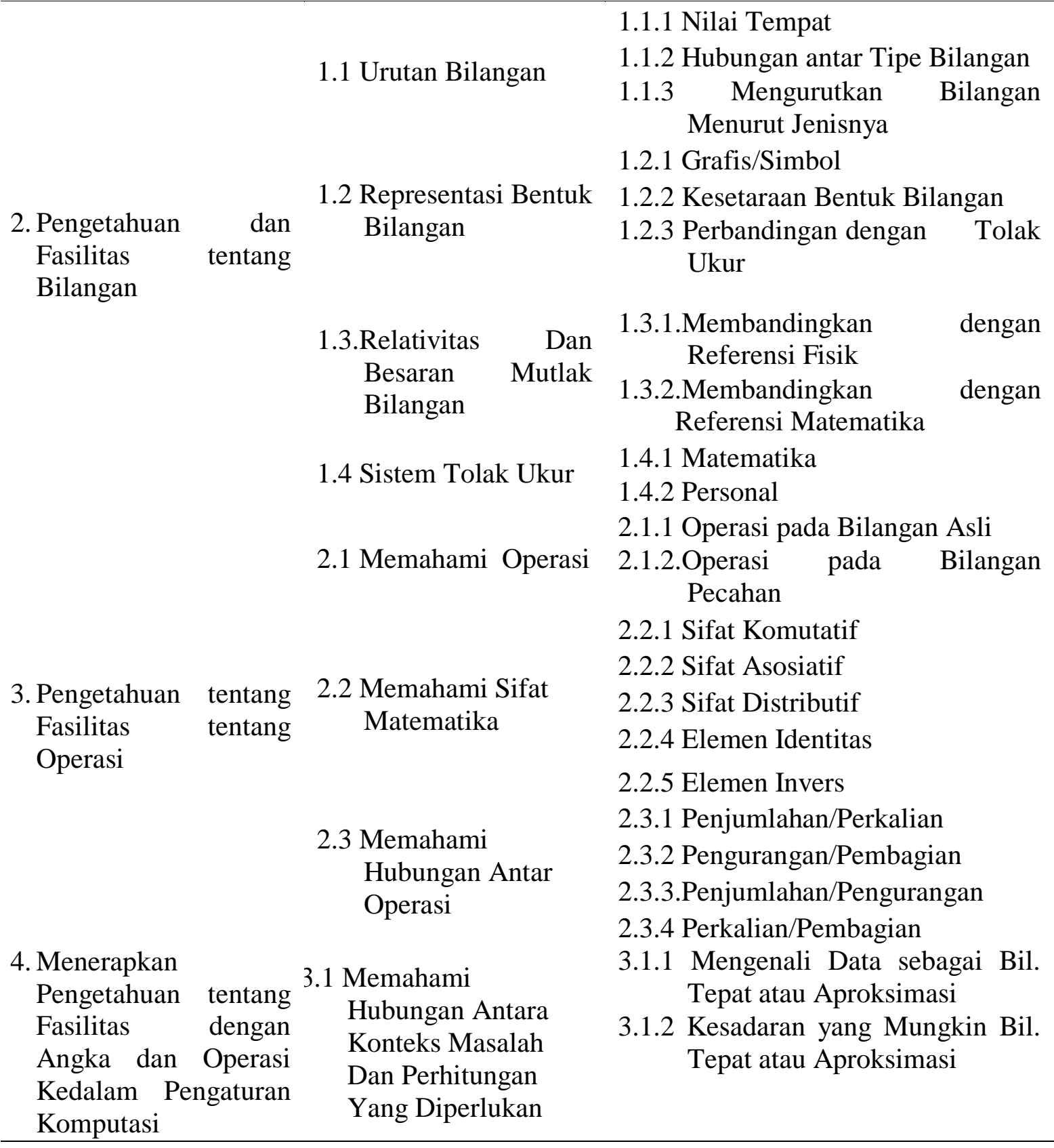

Kemampuan numerik siswa berbeda-beda. Ada siswa yang memiliki kemampuan numerik yang tinggi dan ada pula yang rendah. Siswa yang mempunyai kemampuan numerik yang tinggi akan bekerja lebih baik dalam berhitung sedangkan siswa yang mempunyai kemampuan numerik rendah cenderung akan mengalami kesulitan dalam berhitung.
Pengembangan kemampuan numerik ini dapat membekali siswa berpikir logis, analitis, sistematis, kritis, dan kreatif. Sayangnya, proses pembelajaran matematika belum mengupayakan terbentuknya kemampuan ini yang dilaksanakan pada jenjang pendidikan formal di daerah pesisir. Upaya ini dapat diwujudkan melalui evaluasi untuk mengetahui kemampuan numerik siswa pesisir. 
Berdasrkan wawancara yang dilakukan dengan siswa di SMP pesisir, siswa merasa mata pelajaran yang paling susah adalah matematika. Kemampuan siswa dalam soal hitung-mengitung seperti dalam operasi penjumlahan, pengurangan, perkalian dan pembagian masih kurang. Faktor yang menyebabkan hal tersebut adalah kebanyakan siswa saat di rumah tidak mengulangi materi yang telah diajarkan di sekolah, sebagian besar waktu

\section{METODE PENELITIAN}

Penelitian ini adalah penelitian deskriptif eksploratif dengan perolehan data menggunakan deskriptif kuantitatif. Dalam penelitian ini tidak ada hipotesis. Perhatian utama dalam penelitian ini adalah hasil tes kemampuan numerik siswa. analisis hasil tes siswa tersebut menyajikan jawaban terhadap permasalahan penelitian ini. Penelitian ini dilaksanakan pada semester genap Tahun ajaran 2017/2018 di SMP Negeri di Kabupaten Wakatobi

Populasi dalam penelitian ini adalah seluruh siswa SMP Negeri yang ada di Kabupaten Wakatobi. Populasi tersebut diklasifikasikan berdasarkan letak dan karakteristik wilayah yang ada di Kabupaten Wakatobi. Sampel penelitian adalah kelas VIII. Penentuan sampel dalam penelitian ini dilakukan dengan menggunakan teknik purposive sampling. Teknik pemilihan kelas pada sampel penelitian dari tiap tiap sekolah dilakukan secara random sampling.

Instrumen yang digunakan untuk melengkapi data dan membandingkan data yang telah ditemukan yaitu Tes kemampuan numerik yang digunakan untuk mengetahui kemampuan numerik siswa pesisir SMP Negeri yang ada di Kabupaten Wakatobi yang berkaiatan dengan pengetahuan dan fasilitas tentang bilangan, Pengetahuan Fasilitas tentang Operasi, dan Menerapkan Pengetahuan tentang Fasilitas dengan Angka dan Operasi Kedalam Pengaturan Komputasi. siswa dihabiskan untuk bermain atau membantu orang tua mencari nafkah sehingga kemampuan numerik siswa rendah.

Menyadari berbagi kondisi yang telah dipaparkan di atas, penulis ingin mengangkat penelitian dengan judul penelitian "Kemampuan Numerik Siswa Pesisir SMP Negeri di Kabupaten Wakatobi"

Tes dalam penelitian ini berjumlah 40 butir soal dalam bentuk pilihan ganda yang disusun oleh peneliti.

Teknik pengumpulan data dalam penelitian ini adalah pemberian tes. Tes yang dilakukan dalam penelitian ini adalah tes tertulis. Tes disusun oleh peneliti dan dikonsultasikan dengan guru dan kedua dosen pembimbing. Tes bertujuan untuk mengetahui tentang kemampuan numerik siswa yang berkaiatan dengan pengetahuan dan fasilitas tentang bilngan, pengetahuan tentang fasilitas operasi, dan menerapkan pengetahuan tentang fasilitas dengan angka dan operasi kedalam pengaturan komputasi

Data dalam penelitian ini adalah data kuantitatif yang diperoleh melalui nilai siswa pada hasil Tes Kemampuan Numerik Siswa. Nilai siswa tersebut dianalisis secara deskriptif untuk menggambarkan kemampuan siswa dalam menyelesaikan soal-soal kemampuan numerik.

Analisis yang digunakan untuk mengembangkan keadaan sampel dalam bentuk, rata-rata $(\bar{x})$, standar deviasi $(\mathrm{S})$, persentase $(\%)$, nilai maksimum $\left(\mathrm{x}_{\max }\right)$, nilai minimum $\left(\mathrm{x}_{\min }\right)$, dan grafik/ tabel.

Persentase kemampuan numerik siswa digunakan rumus sebagai berikut.

Keterangan:

$$
X=\frac{S S}{S T} \times 100 \%
$$

$\mathrm{X}=$ Persentase kemampuan numerik siswa

$\mathrm{SS}=$ Skor siswa 
ST $=$ SkorTotal

Nilai perolehan siswa tersebut merupakan data penelitian ini. Apabila siswa memperoleh skor $(X \geq 80)$ maka siswa dikatakan memiliki kemampuan numerik yang "tinggi", apabila siswa memperoleh skor $(60 \leq \mathrm{X}<80)$ maka siswa dikatakan memiliki kemampuan numerik "sedang", dan apabila siswa memperoleh skor $(X<60)$ maka siswa

\section{HASIL PENELITIAN}

Berdasarkan hasil analisis data tes kemampuan numerik siswa pada pelajaran matematika yang diperoleh melalui soal kemampuan numerik, statistik deskripsi kemampuan numerik siswa pada pelajaran matematika siswa SMP Negeri di Kabupaten Wakatobi Tahun Pelajaran 2017/2018 berkisar antara 10 (skor dikatakan memiliki kemampuan numerik "rendah" (Kunandar, 2014: 130).

Data dalam penelitian ini akan disajikan dalam bentuk tabel dan grafik. Data tersebut juga disajikan dan dianalisis berdasarkan jenis soal dan indikator Tes Kemampuan Numerik, sehingga dapat diketahui apa yang masih merupakan masalah bagi siswa SMP pesisir di Kabupaten Wakatobi dan materi apa yang sudah baik.

minimum) sampai dengan 65 (skor maksimum). Rata-rata nilai kemampuan numerik siswa adalah 29,71, standar deviasi adalah 8,87, median adalah 28,75 dan modus adalah 35. Statistik deskripsi kemampuan numerik siswa pada pelajaran matematika selengkapnya dapat dilihat pada Tabel 2 .

Tabel 2. Deskripsi Kemampuan Numerik Siswa pada setiap sekolah

\begin{tabular}{|c|c|c|c|c|c|c|c|}
\hline No & Sekolah & $\bar{x}$ & Min & Max & Modus & Median & $\begin{array}{l}\text { Standar } \\
\text { Deviasi }\end{array}$ \\
\hline 1 & $\begin{array}{l}\text { SMPN } 1 \text { Wangi- } \\
\text { Wangi }\end{array}$ & 29,26 & 13,33 & 60 & 33,33 & 30,00 & 11,22 \\
\hline 2 & $\begin{array}{l}\text { SMPN } 2 \text { Wangi- } \\
\text { Wangi }\end{array}$ & 30,16 & 16,67 & 56,67 & 23,33 & 30,00 & 9,40 \\
\hline 3 & $\begin{array}{l}\text { SMPN } 1 \text { Wangi - } \\
\text { Wangi Selatan }\end{array}$ & 28,61 & 28,61 & 46,67 & 36,67 & 30,00 & 8,73 \\
\hline 4 & SMPN 1 Kaledupa & 27,25 & 10,00 & 66,67 & 20,00 & 23,33 & 11,83 \\
\hline 5 & SMPN 2 Kaledupa & 22,63 & 10,00 & 40,00 & 23,33 & 23,33 & 6,99 \\
\hline 6 & SMPN 1 Tomia & 33,81 & 16,67 & 83,33 & 30,00 & 30,00 & 14,73 \\
\hline 7 & SMPN 2 Tomia & 36,67 & 16,67 & 56,67 & 30,00 & 35,00 & 11,25 \\
\hline 8 & SMPN 1 Binongko & 30,29 & 13,33 & 53,33 & 23,33 & 30,00 & 9,10 \\
\hline \multirow[t]{2}{*}{9} & SMPN 4 Binongko & 28,24 & 3,33 & 46,67 & 23,33 & 26,67 & 11,91 \\
\hline & Gabungan & 29,85 & 3,33 & 83,33 & 23,33 & 30,00 & 11,19 \\
\hline
\end{tabular}

Sumber: Data diolah dengan program Microsoft Excel 2007

Hasil kemampuan numerik yang disajikan pada Tabel 2 diatas menunjukkan bahwa rata-rata kemampuan numerik siswa SMPN 2 Tomia lebih baik dibandingkan dengan ke 8 sekolah yang menjadi sampel penelitian di Kabupaten
Wakatobi kemudian diikuti SMPN 2 Tomia ebagai rata-rata tertinggi urutan kedua. Namun, ke 9 sekolah yang menjadi sampel penelitian berada pada kategori kemampuan numerik rendah. 
Tabel 3. Persentase Kemampuan Numerik antara Sekolah yang menjadi sampel penelitian

\begin{tabular}{|c|c|c|c|c|}
\hline \multicolumn{2}{|c|}{ Kategori Kemampuan Numerik } & \multirow{2}{*}{$\begin{array}{c}\text { Frekuansi } \\
0\end{array}$} & \multirow[t]{2}{*}{$\begin{array}{c}\text { Frekuensi } \\
\text { Total }\end{array}$} & \multirow[t]{2}{*}{$\begin{array}{c}\text { Persentase } \\
(\%)\end{array}$} \\
\hline \multirow{11}{*}{ Tinggi } & SMP N 1 Wangi-Wangi & & & \\
\hline & SMP N 2 Wangi-Wangi & 0 & & \\
\hline & SMPN 1 Wangi Wangi Selatan & 0 & & \\
\hline & SMP N 1 Kaledupa & 0 & & \\
\hline & SMP N 2 Kaledupa & 0 & 1 & 0,5 \\
\hline & SMP N 1 Tomia & 1 & & \\
\hline & SMP N 2 Tomia & 0 & & \\
\hline & SMP N 1 Binongko & 0 & & \\
\hline & SMP N 4 Binongko & 0 & & \\
\hline & SMP N 1 Wangi-Wangi & 1 & & \\
\hline & SMP N 2 Wangi-wangi & 0 & & \\
\hline \multirow{6}{*}{ Sedang } & SMP N 1 Wangi-wangi Selatan & 0 & & \\
\hline & SMP N 1 Kaledupa & 1 & & \\
\hline & SMP N 2 Kaledupa & 0 & 2 & 1 \\
\hline & SMP N 1 Tomia & 0 & & \\
\hline & SMP N 2 Tomia & 0 & & \\
\hline & SMP N 1Binongko & 0 & & \\
\hline \multirow{11}{*}{ Rendah } & SMP N 4 Binongko & 0 & & \\
\hline & SMP N 1 Wangi-Wangi & 26 & & \\
\hline & SMP N 2 Wangi-wangi & 21 & & \\
\hline & SMP N 1 Wangi-wangi Selatan & 24 & & \\
\hline & SMP N 1 Kaledupa & 22 & & \\
\hline & SMP N 2 Kaledupa & 19 & I96 & 98,5 \\
\hline & SMP N 1 Tomia & 20 & & \\
\hline & SMP N 2 Tomia & 24 & & \\
\hline & SMP N 1Binongko & 23 & & \\
\hline & SMP N 4 Binongko & 17 & & \\
\hline & Total & 199 & 199 & $100 \%$ \\
\hline
\end{tabular}

Sumber: Data diolah dengan program Microsoft Excel 2007.

Tabel 3 menunjukkan bahwa pada kategori kemampuan numerik tinggi hanya 1 orang yang memiliki kemampuan numerik tinggi dari 199 siswa. Pada kategori kemapuan numerik sedang hanya 2 orang yang memiliki kemampuan numerik kategori sedang dari 199 siswa yang menjadi sampel penelitian. Pada kategori kemampuan numerik rendah terdapat 196 siswa yang memiliki kemampuan numerik kategori rendah dari 199 siswa yang menjadi sampel penelitian.
Ini menunjukkan bahwa kemampuan numerik siswa pesisir SMP Negeri di Kabupaten Wakatobi adalah rendah dengan persentase $98,5 \%$. Siswa yang memiliki kemampuan sedang hanya ada 2 siswa masing-masing 1 siswa dari SMPN 1 Wangi-wangi dan 1 siswa dari SMPN 1 Kaledupa dan siswa yang memiliki kemampuan numerik pada kategori tinggi hanya ada 1 Orang yaitu siswa dari SMPN 1 Tomia 


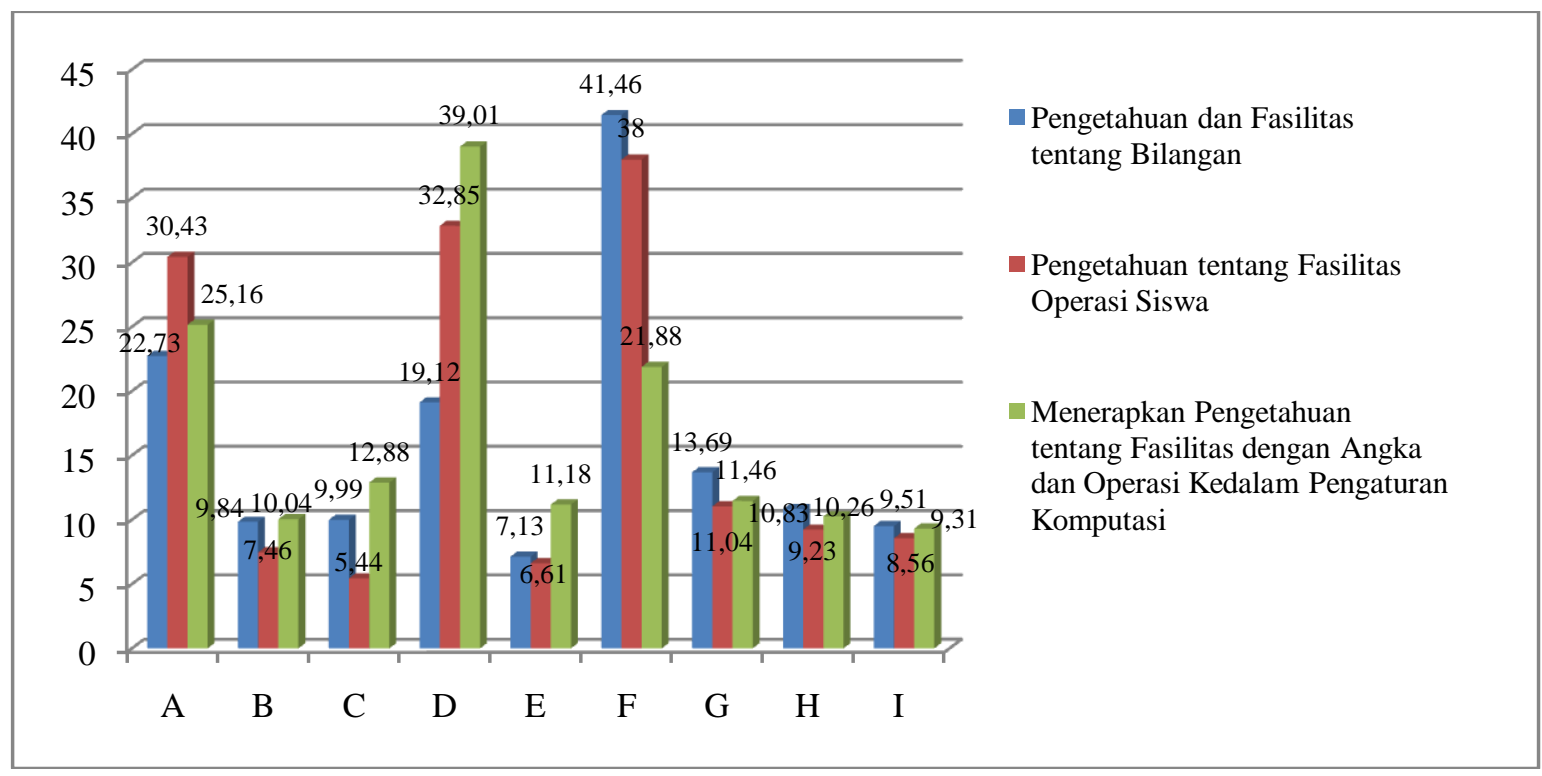

\section{Gambar 1. Diagram Persentase Kemampuan numerik dalam Setiap Jenis Soal}

Hasil pada Gambar 1 menunjukkan bahwa:

1. SMPN 1 Wangi-wangi lebih unggul pada kategori soal pengetahuan tentang fasilitas operasi siswa dengan persentase $30,43 \%$

2. SMPN 2 Wangi-wangi lebih unggul pada kategori soal menerapkan pengetahuan dan fasilitas dengan Bilangan dan operasi kedalam pengaturan komputasi dengan persentase sebesar 10,04\%

3. SMPN 1 Wangi-wangi selatan lebih unggul pada kategori soal menerapkan pengetahuan tentang fasilitas dengan Bilangan dan operasi kedalam pengaturan komputasi dengan persentase sebesar $12,88 \%$.

4. SMPN 1 Kaledupa lebih unggul pada kategori soal menerapkan pengetahuan

\section{PEMBAHASAN}

Pada uraian analisis data secara deskriptif menunjukkan bahwa kemampuan numerik siswa pesisir SMP Negeri di Kabupaten Wakatobi masih sangat rendah. Hal ini merujuk pada tabel 1 yang menunjukkan bahwa nilai rata-rata tentang fasilitas dengan Bilangan dan operasi kedalam pengaturan komputasi dengan persentase sebesar 39,01\%

5. SMPN 2 Kaledupa lebih unggul pada kategori soal menerapkan pengetahuan tentang fasilitas dengan Bilangan dan operasi kedalam pengaturan komputasi dengan persentase sebesar $11,18 \%$

6. SMPN 1 Tomia unggul dalam kategori soal pengetahuan dan fasilitas tentang bilangan dengan persentase sebesar $41,46 \%$.

7. SMPN 2 Tomia unggul dalam kategori soal pengetahuan dan fasilitas tentang bilangan dengan persentrasi sebesar $13,69 \%$.

8. SMPN 1 Binongko pengetahuan dan fasilitas tentang bilangan dengan persentase sebesar 10,83\%.

gabungan dari 9 sekolah tersebut adalah 29,85 .

Persentase kemampuan numerik siswa yang merujuk pada Tabel 3 yang menunjukkan bahwa persentase kemampuan numerik siswa dalam kategori rendah sebesar 98,5\%, sedangkan 
peresentase kemampuan numerik siswa dalam kategori sedang hanya mampu mencapai sebesar $1 \%$ saja yaitu hanya pada siswa di SMPN 1 Wangi-wangi dan siswa di SMPN 1 Kaledupa. Persentase kemampuan numerik siswa dalam kategori tinggi hanya mampu mencapai sebesar $0,5 \%$ yaitu hanya pada siswa di SMPN 1 Tomia.

Tabel 4 Persentasi Kemampuan Numerik Tiap Pulau

\begin{tabular}{llll}
\hline \multicolumn{2}{c}{ Kategori Kemampuan Numerik } & Rata- rata & $\begin{array}{c}\text { Persentase } \\
(\%)\end{array}$ \\
\hline \multirow{2}{*}{$\begin{array}{l}\text { Pulau } \\
\text { wangi }\end{array}$} & SMP N 1 Wangi-Wangi & 29,26 & 29,34 \\
& SMP N 2 Wangi-Wangi & 30,16 & \\
Pulau Kaledupa & SMP N 1 Wangi Wangi Selatan & 28,61 & \\
\multirow{4}{*}{ Pulau Tomia } & SMP N 1 Kaledupa & 27,25 & 24,94 \\
\multirow{4}{*}{ Pulau Binongko } & SMP N 2 Kaledupa & 22,63 & \\
& SMP N 1 Tomia & 33,81 & 35,24 \\
& SMP N 2 Tomia & 36,67 & \\
& SMP N 1 Binongko & 30,29 & 29,27 \\
& SMP N 4 Binongko & 28,24 & 118,79 \\
\hline
\end{tabular}

Pada tabel 4 menunjukkan bahwa di tiap pulau yang ada di Kabupaten Wakatobi memiliki kemampuan numerik pada kategori rendah. Sesuai dengan teori yang di kemukakan oleh Kumandar (2014) bahwa apabila persentase kemampuan numerik yang diperoleh siswa yaitu $\mathrm{X}<$ 60 maka kemampuan numerik di

\section{KESIMPULAN DAN SARAN}

Berdasarkan hasil analisis dan pembahasan maka dapat disimpulkan sebagai berikut:

1. Kemampuan numerik siswa pesisir di Kabupaten Wakatobi masih sangan rendah, kemampuan numerik kategori rendah dengan persentasi 98,5\%, kemudian kategori sedang $1 \%$ dan kategori tinggi $0,5 \%$.

2. Kemampuan numerik siswa SMPN di Kabupaten Wakatobi pada kategori rendah, dimana pulau yang memiliki kemampuan numerik yang baik secara berurutan adalah pulau Tomia dengan persentase $35,24 \%$, pulau wangi-wangi dengan persentase 29,34\%, pulau kategorikan sebagai kemampuan numerik kategori rendah.

Uraian diatas menunjukkan bahwa kemampuan numerik siswa pesisir di Kabupaten Wakatobi masih sangant rendah, Kemampuan numerik kategori rendah dengan persentasi $98,5 \%$, kemudian kategori sedang $1 \%$ dan kategori tinggi $05 \%$

Binongko dengan persentase 29,27\% dan pulau Kaledupa dengan persentase 24,94\%.

Berdasarkan kesimpulan yang telah diuraikan, saran yang dapat diberikan adalah sebagai berikut.

1. Karena kemampuan numerik siswa dipesisir masih rendah, maka perlu adanya solusi mengenai strategi, pendekatan, dan metode tertentu yang dapat meningkatkan kemampuan numerik siswa. Kemampuan numerik siswa dapat dikembangkan dengan sering melatih siswa mengerjakan soal-soal number sense sehingga 
siswa kreatif dalam menyelesaikan suatu soal matematika.

2. Perlu dilakukan penelitian lanjutan terhadap faktor-faktor yang

\section{DAFTAR PUSTAKA}

Bangend.G .2001. Ekosistem dan Sumber Daya Alam Pesisir dan Laut. Bogor: PKSPL-PB.

Dahuri R, Rais Y, Putra SG, Sitepu, M.J. 2001. Pengelolaan Sumberdaya Wilayah Pesisir dan Lautan Secara Terpadu. Jakarta: Pradnya Paramita.

Fudyantanta. 2004. Tes Bakat dan Penalaran Kecerdasan. Yogyakarta: Pustaka Belajar.

Gardner, H. 1993. multiple inteligencies.Jakarta: PT Gramedia pustaka.

Kay, A and Alder, W. 1999. Costal Planning And Management. Bandung: Mandar maju.

Kadir. 2009. Peningkatan Kemampuan Pemecahan Masalah Matematik Siswa SMP melalui Penerapan Pembelajaran Kontekstual Pesisir. Seminar Nasional Matematika dan Pendidikan Matematika. 3 (2), 428440.

Kusnadi. 2007. Strategi Hidup Masyarakat Nelayan. Yogyakarta: LKIS

Kunandar. 2014. Penilaian Autentik (Penilaian Hasil Belajar Peserta Didik Berdasarkan Kurikulum 2013) Suatu Pendekatan Praktis Edisi Revisi. Jakarta: Rajawali Press.

Leoni, A. 2008. Super Tes IQ. Tangerang: PT Tangga Pustaka.

Reys, R., Reys, B., McIntosh, A., Emanuelsson, G., Johansson, B., \& Der, C.Y.1999. Assessing number sense of students in Australia, Sweden, Taiwan, and the United mempengaruhi lemahnya kemampuan numerik di sekolah pesisir

States. School Science and Mathematics, 99: 61-70.

Robbins, S. P. 2006. Perilaku Organisasi. Edisi Kesepuluh. Jakarta: PT. Indeks Kelompok Gramedia.

Supriharyono. 2007. KonseRvasi Ekosistem Sumberdaya Hayati. Yogyakarta: Pustaka Pelajar. 